\title{
Meningkatkan Kemampuan Membaca Puisi Melalui Penerapan Model Dramatic Learning Kelas IV SDN 4 Tugu Tasikmalaya
}

\author{
Anisa Pitriani ${ }^{1}$, Dedi Heryadi ${ }^{2}$, Riga Zahara Nurani ${ }^{3}$ \\ 1,3Universitas Perjuangan Tasikmalaya, ${ }^{2}$ Universitas Pendidikan Indonesia \\ anisa@gmail.com
}

\section{Article History}

accepted 2/11/2019

approved $23 / 11 / 2019$

published 31/12/2019

\begin{abstract}
The research is aimed to describe the model of learning dramatic than can improve the ability to read poetry student grade IV SDN 4 Tugu Tasikmalaya. Lack of ability to read poetry students in the eyes of subjects Indonesian be the focus of the main researchers in the study of this. Learning that is less attractive with methods Research Action Class models Kemmis and Mc. Taggart which consists of planning, implementation, observation, and reflection. This research was conducted in 2 cycles, each cycle consisting of 2 meetings. Instruments are used in research of this sheet tests, observation, and documentation. The results of data analysis showed that the implementation of the ability to read poetry through the application of a dramatic learning model in class IV SDN 4 Tugu Tasikmalaya can be increased in reading poetry of students. Increased students ability read poetry seen from the average value at 75,78 pre-action. In first cycle the value of the average is 76 . And the second cycle reached the value af the average is 77 . Based on the results of the actions the ability to read a poetry seen that they are more increases in the ability to read poetry. Using a dramatic learning models in the process of learning to read poetry.
\end{abstract}

Keyword : Dramatic Learning Model, Ability Reading Poetry

\begin{abstract}
Abstrak
Penelitian ini bertujuan untuk mendeskripsikan model pembelajaran dramatic learning yang dapat meningkatkan kemampuan membaca puisi siswa kelas IV SDN 4 Tugu Tasikmalaya,. Rendahnya kemampuan membaca puisi siswa pada mata pelajaran Bahasa Indonesia menjadi fokus utama peneliti dalam penelitian ini. Pembelajaran yang kurang menarik dengan metode konvensional serta tidak terbangunnya semangat siswa selama proses pembelajaran menjadi penyebab masalah tersebut. Maka dari itu, peneliti mencoba melakukan perbaikan pembelajaran dengan metode Penelitian Tindakan Kelas ( PTK) model kemmis dan Mc taggart yang terdiri dari perencanaan, pelaksanaan, observasi, dan refleksi. Penelitian ini dilaksanakan dalam 2 siklus, masing-masing siklus terdiri dari 2 pertemuan. Instrumen yang digunakan dalam penelitian ini lembar tes, observasi, dan dokumentasi. Hasil analisis data diperoleh bahwa pelaksanaan kemampuan membaca puisi melalui penerapan model dramatic learning di kelas IV SDN 4 Tugu Tasikmalaya dapat meningkat dalam membaca puisi siswa. Meningkatnya kemampuan membaca puisi siswa dilihat dari nilai rata pada pra tindakan 75,78 . Pada siklus I mencapai nilai rata-rata 76. Dan siklus II mencapai nilai rata-rata mencapai 77 . Berdasarkan hasil tindakan kemampuan membaca puisi terlihat bahwa mereka lebih meningkat dalam kemampuan membaca puisi. Menggunakan model dramatic learning dalam proses belajar membaca puisi.
\end{abstract}

Kata Kunci: Model Dramatic Learning, Kemampuan Membaca Puisi

Social, Humanities, and Education Studies (SHEs): Conference Series https://jurnal.uns.ac.id/shes

p-ISSN 2620-9284

e-ISSN 2620-9292

This work is licensed under a Creative Commons Attribution-ShareAlike 4.0 International License. 


\section{PENDAHULUAN}

Membaca merupakan salah satu keterampilan berbahasa yang diajarkan dalam mata pelajaran Bahasa Indonesia di Sekolah Dasar. Sementara itu dalam pengertian Nurhadi (2016:43) bahwa "Membaca adalah Proses pengolahan bacaan secara kreatif yang dilakukan pembaca untuk memperoleh pemahaman menyeluruh tentang bacaan itu yang diikuti penilaian terhadap keadaan, nilai, fungsi, dan dampak bacaan itu.

Berdasarkan hasil penelitian Rusyana (2011:15) bahwa: "Di dalam pembelajaran Bersastra dikehendaki terjadinya kegiatan bersastra, yaitu menggunakan bahasa dan estetika. Jadi, berbagai unsur sastra, seperti tokoh, penokohan, alur cerita, latar cerita, didalam prosa, ataupun kegiatan mendengarkan, kegiatan berbicara, membaca, digunakan dalam berapresiasi, yaitu oleh seseorang dalam berhubungan dengan karya sastra. Sastra di dalam kegiatan berapresiasi digunakan bertukar pikiran, perasaan, pendapat, imajinasi, dan sebagainya sehingga terjadi kegiatan baik jasmani ataupun rohani.

Kemampuan membaca puisi awalnya ketika penulis memberikan tes membaca puisi pada pra tindakan kepada siswa, siswa kurang dalam memberikan respon terhadap materi membaca puisi yang diberikan oleh penulis. Jawaban yang diberikan oleh siswa hanya sebatas hafalan. Keingintahuan siswa terhadap suatu konsep membaca puisi masih rendah.

Berkaitan dengan hal tersebut di atas, penulis membuat latar belakang ini berdasarkan permasalahan dikelas IV SDN 4 Tugu Tasikmalaya yaitu ada beberapa hal yang menyebabkan permasalahan itu muncul, antara lain siswa tidak berani tampil dan membaca dengan baik. Hal ini dapat dibuktikan dari hasil membaca puisi pra tindakan sebagai berikut:

Tabel 1 Nilai Kemampuan Membaca Puisi Pada Kondisi Awal

\begin{tabular}{|l|c|c|c|c|c|c|}
\hline & Nada & Intonasi & Mimik & Vokal & Skor Nilai & $\begin{array}{c}\text { Nilai Rata - } \\
\text { rata }\end{array}$ \\
\hline $\begin{array}{l}\text { Jumlah } \\
\text { Skor }\end{array}$ & 2498 & 2534 & 2455 & 2398 & 10046 & 2501,50 \\
\hline $\begin{array}{l}\text { Nilai Rata - } \\
\text { rata }\end{array}$ & 75,69 & 76,78 & 74,39 & 72,66 & 304,42 & 75,78 \\
\hline
\end{tabular}

Dari 33 siswa yang mengikuti Tes membaca puisi pada pra tindakan yang belum tuntas ada 8 orang, yang tuntas 25 orang. Dapat dilihat siswa 1 mendapat nilai rata rata78,75, siswa 2 mendapat nilai rata- ratanya 76,00, siswa 3 mendapat nilai rata-ra 77,50 , siswa 4 mendapat nilai rata-rata 73,00, siswa 5 mendapat nilai rata-rata 78,75 , siswa 6 mendapat nilai rata-rata 78,75, siswa 7 mendapat nilai rata-rata 76,25, siswa 8 mendapat nilai rata- rata 76,50, siswa 9 mendapat nilai rata-rata 73,00 , siswa 10 mendapat nilai rata-rata 78,00, siswa 11 mendapat nilai rata-rata77,75, siswa 12 mendapat nilai rata-rata 77,75, siswa 13 mendapat nilai rata-rata 77,00, siswa 14 mendapat nilai rata-rata 72,75 , siswa 15 mendapat nilai rata-rata 73,00, siswa 16 mendapat nilai rata-rata 76,75, siswa 17 mendapat nilai rata-rata 76,50, siswa 18 mendapat nilai rata- rata76,50, siswa 19 mendapat nilai rata-rata 77,00, siswa 20 mendapat nilai rata-rata 73,00, siswa 21 mendapat nilai rata -rata 76,50, siswa 22 76,50, siswa 22 mendapat nilai rata 78,25, siswa 23 mendapat nilai rata-rata 76,25, siswa 24 mendapat nilai rata-rata 77,50, siswa 25 mendapat nilai rata-rata 76,25, siswa 26 mendapat nilai rata- rata 76,00, siswa 27 mendapat nilai rata 76,00, siswa 28 
mendapat nilai rata-rata 73,75, siswa 29 nilai rata-rata 73,00, siswa 30 mendapat nilai rata-rata 77,25, siswa 31 mendapat nilai rata-rata 77,25, siswa 32 mendapat nilai ratarata 76,50 dan siswa 33 mendapat nilai rata-rata 78,25. Jadi kesimpulan dari tes kemampuan membaca puisi pada pra tindakan cara menghitung nilai rata-rata rumusnya ysebagai berikut : Analisis data hasil tes kemampuan membaca puisi siswa dapat dilihat pada setiap siklus dilakukan satu kali tes evaluasi. Skor maksimal yang diperoleh siswa adalah 100, sedangkan skor rata-rata dihitung dengan rumus:

Keterangan:

$$
X=\frac{\Sigma}{N}
$$

$x=$ Nilai Rata- rata

$\sum \mathrm{x}=$ Jumlah Skor Keseluruhan

$N=$ Jumlah Siswa

Untuk memperbaiki permasalahan tersebut penggunaan model dramatic learning dapat membantu menerapkan suatu cara bahan-bahan pelajaran melalui pengembangan imajinasi dan penghayatan yang dilakukan siswa dalam membaca puisi. Dengan menggunakan model dramatic learning diharapkan membantu guru untuk lebih mengetahui kelebihan masing-masing siswa dengan dilatih berpikir logis dan sistematis, meningkatkan siswa dalam perencanaan dan pengelolaan kelas.

Berikut ini adalah penelitian terdahulu yang berkaitan dengan model pembelajaran dramatic learning. Penelitian yang dilakukan oleh Erna Dwi Handayani (2011) yang berjudul" Keterampilan membaca puisi siswa melalui video pembelajaran pada mata pelajaran Bahasa Indonesia di kelas V di SD Ngadirgo Mijen Semarang.

Berdasarkan hasil permasalahan tersebut diperoleh kesimpulan bahwa ada peningkatan dalam kemampuan membaca puisi siswa melalui video pada mata pelajaran bahasa Indonesia dengan materi Keterampilan membaca puisi di SD Ngadirgo Mijen Semarang. Dilihat dari aspek yang mengalami peningkatan paling tinggi dari pra tindakan nilai rata -ratanya 66,1 atau presentase $45 \%$ sampai siklus I dengan membaca puisi dengan nilai rata-ratanya 74,4 atau persentase $100 \%$ atau sedangkan Tingkat terata pencapaian skor keterampilan membaca puisi pada tahap siklus II nilai rata-ratanya 81,9 atau persentase $100 \%$.

\section{METODE}

Penelitian ini menggunakan desain penelitian menurut Mc Taggart (2018:6) "Bahwa Penelitian tindakan kelas merupakan pengembangan dari model Kurt Lewin. Pada model ini tindakan (acting) dan observasi (observing) dijadikan sebagai satu Kesatuan karena mereka menganggap bahwa kedua komponen tersebut merupakan dua kegiatan yang baik tidak bias dipisahkan. Berikut ini adalah model yang dikembangkan. Jadi pada intinya model ini terdiri dari beberapa tahapan diantaranya: (1) perencanaan (2) tindakan (3) observasi (4) refleksi. Teknik pengumpulan data yang digunakan penelitian ini meliputi tes, observasi, dan dokumentasi . teknik tes digunakan untuk mengumpulkan data berupa kelayakan pembelajaran membaca puisi melalui penerapan model dramatic learning dan teknik observasi digunakan untuk mengumpulkan data berupa rata-rata keterlaksanaan pembelajaran Bahasa Indonesia dengan pembelajaran membaca puisi melalui penerapan model dramatic learning 


\section{HASIL DAN PEMBAHASAN}

\section{HASIL PENELITIAN}

\section{Pra Tindakan}

Pada hari senin tanggal 20 April 2018 Penulis meneliti dikelas IV SDN 4 Tugu Tasikmalaya, pada saat proses pembelajaran berlangsung Penulis menceritakan apa yang akan disampaikan pada hari itu yaitu membaca puisi. Pada kondisi awal siswa diberi pengarahan oleh Penulis dalam membaca puisi yang baik setelah itu siswa melihat bagaimana cara membaca puisi dengan aspek seperti pada nada, intonasi , mimik, dan vokal. Pada kondisi kedua siswa dipersilahkan secara perorangan untuk maju kedepan kelas membaca puisi. Dapat penulis lihat dari semua siswa kelas IV masih malu-malu membacakan sebuah puisi dengan ke empat aspek tersebut. Penulis pada observasi pra tindakan tidak menggunakan model dramatic learning dan hanya menggunakan ceramah. Berdasarkan kesimpulan jadi pembelajaran tidak menggunakan model pembelajaran tidak akan kondusif sehingga masih banyak kekurangan.

Pada kegiatan observasi awal ini bertujuan untuk mengetahui kondisi didalam kelas dan kemampuan siswa dalam membaca puisi. Kemudian dari hasil tes serta pengamatan langsung dalam proses kegiatan pembelajaran di kelas, menunjukan bahwa rata- rata siswa dalam kegiatan membaca puisi masih dianggap kurang. Hal ini sesuai dengan keterangan tabel dibawah ini:

Tabel 1. Nilai Kemampuan Membaca Puisi Pada Pra Tindakan

\begin{tabular}{|r|l|l|l|l|l|l|}
\hline & \multicolumn{6}{|c|}{ Aspek penilaian } \\
\cline { 2 - 7 } & Nada & Intonasi & Mimik & Vokal & $\begin{array}{c}\text { Jumlah } \\
\text { Skor }\end{array}$ & $\begin{array}{c}\text { Nilai Rata- } \\
\text { rata }\end{array}$ \\
\hline Jumlah Skor & 2498 & 2534 & 2455 & 2398 & 10046 & 2501,50 \\
\hline $\begin{array}{r}\text { Nilai Rata - } \\
\text { rata }\end{array}$ & 75,69 & 76,78 & 74,39 & 72,66 & 304,42 & 75,78 \\
\hline
\end{tabular}

\section{Refleksi Pra Tindakan}

Berdasarkan hasil dari Pra siklus dapat diperoleh kesimpulan bahwa pembelajaran yang bersifat konvensional dengan menggunakan ceramah. Hal ini sangat penting untuk dibahas dikarenakan dalam proses belajar mengajar komponen membaca merupakan data komponen yang saling berkaitan, siswa diharapkan mampu dalam membaca puisi.

\section{Siklus I}

Berdasarkan tabel dibawah dari hasil observasi Siklus I yang dilakukan pada kemampuan membaca puisi siswa kelas IV SDN 4 Tugu Tasikmalaya ada 8 orang siswa yang belum bisa membaca puisi. Selain hasil membaca puisi siswa yang telah memenuhi standar dalam membaca puisi mengalami peningkatan yang signifikan. Dapat dilihat pada tabel berikut: 
4th National Seminar on Guidance and Counseling (SNBK 2019) and Workshop on

Pedagogical Theory and Practice (WTPP 2019)

SHEs: Conference Series 2 (2) (2019) $73-79$

Tabel 2. Nilai Kemampuan Membaca Puisi Siklus I

\begin{tabular}{|l|l|c|c|c|c|c|}
\hline & Nada & Intonasi & Mimik & Vokal & Skor Nilai & $\begin{array}{c}\text { Nilai Rata - } \\
\text { rata }\end{array}$ \\
\hline $\begin{array}{l}\text { Jumlah } \\
\text { Skor }\end{array}$ & 2287 & 2425 & 2373 & 2520 & 10,678 & 2508 \\
\hline $\begin{array}{l}\text { Nilai Rata - } \\
\text { rata }\end{array}$ & 69,30 & 73,48 & 71,90 & 76,36 & 323,57 & 76,00 \\
\hline
\end{tabular}

\section{Refleksi Siklus I}

Pertama, dalam proses pembelajaran penulis belum sepenuhnya mengacu pada RPP yang telah dibuat sehingga masih terdapat kegiatan yang tidak dilaksanakan sesuai perencanaan

Kedua, Penjelasan penulis cukup menguasai dengan materi yang diajarkan.

Ketiga, siswa terlihat antusias dan bersemangat dalam berperan aktif dalam membaca puisi dan siswa berperan aktif untuk bertanya tentang materi yang tidak diketahuinya, artinya pembelajaran sudah mulai berpusat kepada siswa, namun dalam kondisi tertentu masih banyak siswa yang tidak mengerti makna pembelajaran yang sedang berlangsung.

Keempat, proses pembelajaran lebih terkondisikan dibanding dengan menggunakan metode ceramah dan Tanya jawab. Karena siswa tertarik dengan model dramatic learning, karena siswa berperan aktif satu persatu dengan model tersebut dalam pembacaan puisi.

Berdasarkan refleksi dari kegiatan pada siklus I masih banyak kekurangan serta kelemahan yang terjadi saat proses pembelajaran berlangsung. Maka dari itu harus dibuat perencanaan kegiatan berikutnya pada siklus II. Perencanaan kegiatan berikutnya pada siklus II. Perencanaan diantaranya adalah perbaikan rencana pelaksanaan pembelajaran yang lebih rinci dan berfokus pada siswa dengan menyusun kegiatan yang lebih bermakna pada saat proses pembelajaran berlangsung.

\section{Siklus II}

Penilaian hasil meningkatkan kemampuan membaca puisi siswa siklus II ini didasarkan pada kriteria dan komponen yang sama dengan hasil penelitian tindakan kelas Pra tindakan, siklus I dan siklus II. Secara rinci kemampuan membaca puisi siklus II dapat diamati sebagai berikut. Dari 33 jumlah siswa pada siklus II meningkat. Adapun penilaian pada Siklus II sebagai berikut dilihat pada tabel berikut:

Tabel 3. Nilai Kemampuan Membaca Puisi Siklus II

\begin{tabular}{|l|c|c|c|c|c|c|}
\hline & Nada & Intonasi & Mimik & Vokal & Skor Nilai & $\begin{array}{c}\text { Nilai Rata - } \\
\text { rata }\end{array}$ \\
\hline $\begin{array}{l}\text { Jumlah } \\
\text { Skor }\end{array}$ & 2621 & 2644 & 2616 & 2544 & 9540 & 2552 \\
\hline $\begin{array}{l}\text { Nilai Rata - } \\
\text { rata }\end{array}$ & 79,42 & 80,12 & 79,27 & 77,09 & 289,09 & 77,33 \\
\hline
\end{tabular}




\section{Refleksi Siklus II}

Penggunaan model dramatic learning siswa lebih berperan aktif dalam kemampuan membaca puisi yang bersifat individu. Hal ini dibuktikan dari hasil kemampuan membaca puisi siswa. Pada pembelajaran Bahasa Indonesia dikelas 1V ini, banyak menuntut siswa untuk berperan aktif dalam proses pembelajaran. berikut:

Untuk membuat siswa lebih meningkat dalam kemampuan membaca sebagai

1. Pemberian motivasi kepada siswa untuk lebih gemar membaca puisi dan lebih ditingkatkan.

2. Peran serta guru dan lingkungan sekitar agar siswa tetap konsisten dalam membaca puisi khususnya dalam pembelajaran Bahasa Indonesia.

Dari tabel diatas dapat dikatakan bahwa kemampuan membaca puisi siswa kelas 1V SDN 4 Tugu Tasikmalaya mengalami peningkatan yaitu Nilai rata - rata siswa 77, 33 . Hal ini berarti bahwa penggunaan model dramatic learning meningkatkan kemampuan membaca puisi siswa. Pelaksanaan penggunaan model dramatic learning dapat menentukan kemampuan membaca puisi siswa sudah meningkat. Pengelolaan kelas yang baik dapat memaksimalkan tercapainya tujuan pembelajaran. Penulis mengarahkan siswa untuk aktif selama pembelajaran berlangsung. Hal ini ditunjukan dengan peran aktif siswa dalam menyampaikan pendapatnya.

\section{PEMBAHASAN}

Berdasarkan Pra tindakan membaca puisi masih kurang. Penelitian mengenai kemampuan membaca puisi melalui penerapan model dramatic learning dilaksanakan dikelas IV SDN 4 Tugu Tasikmalaya. Dalam pelaksanaan penelitian ini penulis sengaja menggunakan model dramatic learning. Dalam pengimplementasiannya, penulis terlebih dahulu menjelaskan secara konseptual mengenai model tersebut, penulis melakukan tes dengan cara menyuruh siswa membaca sebuah puisi didepan teamantemannya. Penulis, menilai siswa begitu antusias saat membaca kan puisi. Akan tetapi dalam pelaksanaan tes tersebut terdapat beberapa siswa yang malu-malu untuk maju kedepan kelas.

Selain itu dari hasil penelitian pada siklus I mulai mengalami peningkatan yang telah dilakukan oleh siswa, diperoleh bahwa pembelajaran membaca puisi dengan menerapkan model dramatic learning telah tercapai dengan baik, yaitu meningkatkan kemampuan membaca puisi pada siswa. Dan pada siklus II maka mengalami peningkatan proses pembelajaran Bahasa Indonesia menggunakan model dramatic learning dapat meningkatkan kemampuan membaca puisi. Hal ini tersebut dapat dilihat rekapitulasi grafik persiklus sebagai berikut:

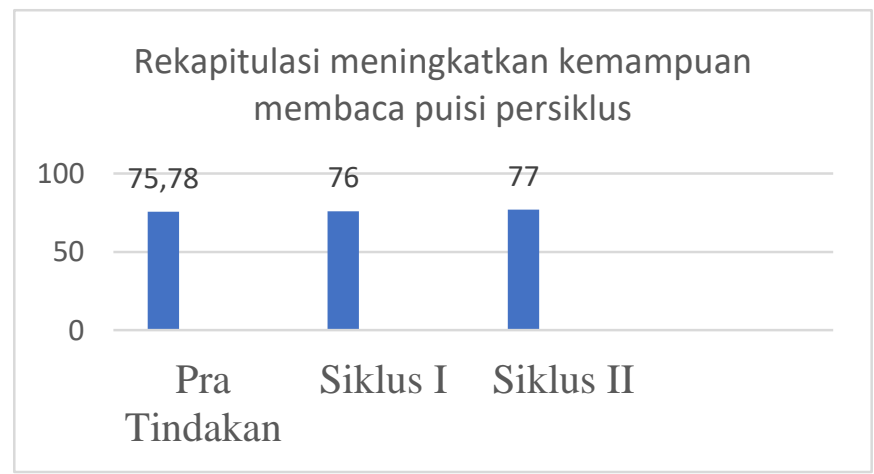

Gambar 1. Rekapitulasi Peningkatan Kemampuan Membaca Puisi 


\section{SIMPULAN}

Hasil pembelajaran meningkatkan kemampuan membaca puisi dengan menggunakan model dramatic learning mengalami peningkatan pada setiap siklusnya. Hal ini dibuktikan dengan berhasilnya penulis memberikan pengarahan. Hal ini dibuktikan pada pra tindakan nilai rata - rata yaitu 75,78 pada siklus I nilai rata ratanya yaitu 76 dan pada siklus II nilai rata- rata siswa meningkat menjadi 77,33 . Peningkatan ini terjadi karena respon dan motivasi eksternal yang diberikan penulis dan motivasi siswa untuk belajar membaca puisi terus meningkat. Hal ini ditujukan dengan perhatian penulis terhadap cara belajar setiap siswa dan keseriusan siswa dalam memperbaiki kesalahan dan kekurangan pada setap siklus pembelajaran. Awalnya siswa kurang percaya diri, malu - malu, kemampuan siswa dalam membaca puisi sangat rendah. Setelah dilaksanakan pembelajaran membaca puisi melalui penerapan model dramatic learning siswa lebih percaya diri, siswa mengetahui teknik membaca puisi yang baik sehingga kemampuan siswa dalam membaca puisi meningkat.

\section{DAFTAR PUSTAKA}

Abidin, Yunus. (2015). Pembelajaran Bahasa Berbasis Pendidikan Karakter. PT. Refika Aditama

Bachri, Syaiful ( 2010). Strategi Belajar Mengajar. Jakarta: Asdi Mahasatya

Cemerlang. (2018). Sastra Indonesia Lengkap. Tangerang: Tim Cemerlang

Handayani . Erna (2011). Peningkatan keterampilan membaca puisi. Fakultas IImu Pendidikan Semarang

Huda Miftahul. (2014). Model-model Pengajaran dan Pembelajaran : PUSTAKA PELAJAR

Mc.Taggart, R \& Kemmis S. (2018). Penelitian Tindakan Kelas. Melbourne. Deakin. Universitya. Aksara

Nurhadi . (2016) . Teknik Membaca. Jakarta :PT Bumi Aksara

Priyanti , Endah Tri. (2014). Keterampilan Membaca. Jakarta: Raja Grafindo Persada

Rahim . Farida. (2009). Pengajaran Membaca Di Sekolah Dasar. Jakarta: Bumi Aksara

Rusyana. (2015) . Pedoman Penulisan Buku Teks Pelajaran Bahasa Indonesia SD, SMP, SMP, dan SMA. Jakarta : Pusat Perbukuan Depdiknas

Santoso. ( 2011). Keunggulan model dramatic learning. Jakarta Persada 